\title{
Isolation and identification of bacteria from tracheas and lungs of buffaloes in Dinajpur
}

\author{
Md. Zulfekar Ali ${ }^{1+}$ and Shirin Sultana ${ }^{2}$ \\ ${ }^{I}$ Nourish Poultry Diseases Diagnostic Laboratory, Unit-2, Bogra, Bangladesh; ${ }^{2}$ Department Pathology and Parasitology, Hajee \\ Mohammad Danesh Science and Technology University (HSTU), Basherhat, Dinajpur - 5200, Bangladesh
}

Received 09 January 2012/Accepted 17 April 2012

\begin{abstract}
The aim of the present study was the isolation and identification of bacteria from trachea and lung of slaughtered buffaloes. A total of 160 swab samples were collected from tracheas (80) and lungs (80) freshly slaughtered buffeloes from the slaughter houses of Dinajpur Sadar, Dinajpur, Bangladesh, during the period from June 2011 to February 2012. Among them, 9 tracheas (out of 80 samples) and 30 lungs (out of 80 samples) showed visible lesions. Bacterial isolates were identified based on their growth, morphological and biochemical characteristics. The most frequent $(5 \%)$ bacterial isolate in tracheas was Staphylococcus spp. Pasteurella haemolytica and Staphylococcus spp. were isolated from different types of lung lesions in a frequency of $5 \%$ and $16.25 \%$, respectively. $P$. haemolytica showed $\beta$ haemolysis on blood agar and did not ferment lactose and dulcitol whereas dextrose, manitol and maltose were fermented with the production of acid. This investigation would be helpful for veterinarian for the detection, treatment and control of tracheal and lung diseases of buffaloes.
\end{abstract}

Key words: Staphylococcus; Pasteurella; buffaloes

The domestic or water buffalo (Bubalus bubalis) belongs to the genus Bubalus, subfamily Bovaine, family Bovidea, is descended from the Arnior. Wild Indian buffalo is wildly dispersed throughout the southern Asia. It has been suggested that buffaloes were in the service for man as early as 2500 to 2100 B.C. In recent years, the buffalo commonly known as an "Asian animal" has attracted global concern. The buffalo is the dairy, draught and meat providing animal of Asia. The Indian subcontinent is the home of the world's dairy buffaloes. Today in India, the water buffalo is recognized as milk machine. It accounts for more than half of India's total milk production, although it constitutes only one third of total milk production requirement (1). Out of total 2.37 million tons milk, about 0.25 million tons of milk are produced from buffalo in Bangladesh every year (2). The domesticated buffaloes are mainly found in coastal areas of Asia; mainly India, Malaysia, Singapore, Philippines, Thailand, Indonesia, Southern China and other countries in the fareast. Among 138.37 millions of world buffalo populations, 75 millions of buffaloes are found in India, 20 millions in China, 13 millions in Pakistan. 6 millions in Thailand and 4 millions in

${ }^{\ddagger}$ Corresponding author. Mailing address: Dr. Md. Zulfekar Ali, Nourish Poultry Diseases Diagnostic Laboratory, Unit-2, Bogra, Bangladesh; Email: zulfekar_vet@yahoo.com.
Bangladesh (2).

Like other animals, buffaloes are susceptible to various diseases. Their respiratory system is commonly exposed to the various deleterious agents like bacteria, virus, fungi etc. due to its direct interaction with the external environment (3). Lungs, the main organ of the respiratory system, are susceptible to various parasites as well as the microorganisms which pose harmful effect to the body. Therefore, this investigation has been undertaken for the isolation and identification of the bacteria commonly available in the tracheas and lungs of buffaloes in Bangladesh.

\section{MATERIALS AND METHODS}

Collection of samples. Samples of trachea and lungs were collected from buffaloes after slaughtering from slaughterhouses of Dinajpur Sadar, Dinajpur, Bangladesh during the period from June 2011 to February 2012. A total of 160 sterile swabs, of which 80 from mucosal surface of trachea and 80 from inner core of lung were collected, immediately after opening the thoracic cavity to avoid contamination. All the samples were collected in nutrient broth and brought to the Microbiology Laboratory of the Department of Microbiology, Hajee Mohammad Danesh Science and Technology University, Dinajpur, Bangladesh for isolation and identification of pathogenic bacteria.

Isolation of Bacteria. Samples were inoculated in nutrient broth and incubated at $37^{\circ} \mathrm{C}$ for 24 hours. From the broth, subcultures were also made on blood agar, MacConkey agar, eosine methylene blue (EMB) agar and nutrient agar, and incubated overnight at $37^{\circ} \mathrm{C}$.

Identification of Pathogenic Bacteria. The representative bacteria were stained using modified Gram's staining $(4,5)$ and Leishman's stain according to the method described by Merchant and Packer (6).

Modified Gram's staining. Ammonium oxalate-crystal violet was applied on the bacterial smear for 1 to 2 minutes, washed with water and Lugol's iodine solution was then applied on slide for 1 to 2 minutes. Then iodine was applied on slide 
following decolorization with a few drops of acetone for 5-15 seconds. After washing with water the smear was counter stained with $0.5 \%$ safranine for 1 to 2 , then washed, air dried and examined.

Leishman's staining. Neat Leishman's stain was added on the bacterial smear for 3 minutes. The stain was diluted gently with double volume of tap water. After 20 minutes excess stain was washed off and air dried.

Acid fast staining (Ziehl-Neelsen's method). Carbol fuschin was applied on heat fixed bacterial smear and heated the underside of slide until steaming (without boiling) for 5-7 minutes and washed thoroughly under running tap water. Acid alcohol was applied for 1 minute, followed by counter staining with methylene blue for 1 minute, then washed and examined (7).

Biochemical Tests. Five basic sugars such as dextrose, dulcitol, lactose, maltose and menthol were used for sugar fermentation test. Besides these, other biochemical tests such as triple sugar iron (TSI) agar test, Voges-Proskuer (VP) tests and indole tests were also performed in this study $(6,7)$.

\section{RESULTS}

Among 80 trachea samples, $4(5 \%)$ exhibited the presence of Staphylococcus spp (Table 1). However, other bacteria was absent in those samples. Among 80 lung samples, Staphylococcus spp. and Pasteurella haemolytica were found in $13(16.25 \%)$ and $4(5 \%)$ samples, respectively (Table 2). P. haemolytica was isolated from the stages of pneumonia (congested stage), bronco pneumonia and fibrinious pneumonia; while Staphylococcus spp. was isolated from chronic interstitial pneumonia, broncho pneumonia, bronchitis, bronchiolitis, pneumonia (congested stage), purulent bronco pneumonia and pleuritis. The isolates were identified based on the characteristics described below.

TABLE 1. Prevalence of bacteria in tracea samples of buffaloes $(n=80)$

\begin{tabular}{ccc}
\hline Isolated Bacteria & $\begin{array}{c}\text { No. of affected } \\
\text { animal }\end{array}$ & $\begin{array}{c}\text { \% of isolated } \\
\text { bacteria }\end{array}$ \\
\hline Staphylococcus spp. & 4 & 5 \\
\hline
\end{tabular}

TABLE 1. Prevalence of bacteria in lung samples of buffaloes $(n=80)$

\begin{tabular}{ccc}
\hline Isolated Bacteria & $\begin{array}{c}\text { No. of affected } \\
\text { animal }\end{array}$ & $\begin{array}{c}\text { \% of isolated } \\
\text { bacteria }\end{array}$ \\
\hline Pasteurella Haemolytica & 4 & 5 \\
Staphylococcus spp. & 13 & 16.25 \\
\hline Total & 17 & 21.25 \\
\hline
\end{tabular}

Cultural Characteristics. Staphylococcus spp. grew well on nutrient agar media and showed smooth circular, opaque often yellow-pigmented colony about $1 \mathrm{~mm}$ in diameter after $24 \mathrm{~h}$ incubation at $37^{\circ} \mathrm{C}$. In nutrient broth, they showed dense turbidity with a powdery deposit. $P$. haemolytica showed smooth, circular, grayish colony about $1 \mathrm{~mm}$ in diameter after $24 \mathrm{~h}$ incubation at $37^{\circ} \mathrm{C}$ on nutrient agar. In nutrient broth, diffused turbidity was obseved. Small grayish hemolytic zones were evident on blood agar media. On MacConkey agar media, they showed small pink colored colonies about 1-2 $\mathrm{mm}$ in diameter.

Morphology. Gram positive, round shaped bacteria occurring either singly or in pair were identified as
Staphylococcus spp. After Gram staining, P. haemolytica appeared Gram negative, bipolar and small rod shaped. In Leishman's stain, bipolar characteristics of the Pasteurella were detected which appeared blue. Negative results were observed after acid fast staining.

Biochemical identification. $P$. haemolytica showed positive reaction in catalase test and negative reaction in indole test. On TSI agar slant, they exhibited yellowish coloration along with blackish colored butt, which indicated the presence of $\mathrm{H}_{2} \mathrm{~S}$ producer organisms. $P$. haemolytica failed to ferment lactose and dulcitol, whereas dextrose, manitol and maltose were fermented with the production of acid.

\section{DISCUSSION}

The causes of bovine tracheitis includes Pasteurella spp., Haemophilus sumnus, Staphylococcus spp., infectious bovine Rhinotracheitis virus, bovine Herpes virus-1, trauma to trachea (Radostits et al, 2002; Jobb et al, 1997). In this study, an attempt was taken for bacterial isolation from trachea and Staphylococcus spp. was isolated from 5\% trachea samples. Staphylococcus spp. might be the major cause of tracheitis, however the role of other causal agents could not be ruled out by the present study.

Pneumonia (chronic interstitial pneumonia, bronchopneumonia, congested stage of pneumonia, fibrinous pneumonia, purulent broncho-pneumonia, fobrino purulent pneumonia, subacute fibrinous pneumonia) caused by different bacteria have been reported by many researchers such as Haemophilus sumnus (8); Clostridium perfringens type-D (9), Pasteurella spp. (8, 10, 11); Mycobacterium sp. $(8,12,13)$ and Staphylococcus spp. (8). However, in the present investigation, only two types of bacteria $P$. haemolytica (5\%) and Staphylococcus spp. $(16.25 \%)$ could be isolated and identified. Similar causal agents were also described by other researhers $(8,11,12)$.

In this study, $P$. haemolytica was isolated as the most prevalent bacteria in the congested stage of pneumonia. So, it was speculated that $P$. haemolytica might be the cause of pneumonia in congested stage as found previously (8). The etiological agent of tuberculosis in buffaloes is Mycobacterium bovis (12) that causes nodular lesion in lungs though, no bacteria were found in section of lung nodules as observed through acid fast staining.

In conclusion, this study on trachea and lung samples collected from buffaloes has focused the different diseases and the detection of pathogenic bacteria in those organs. These findings would be helpful to diagnose the etiological agents and their prevalence in respiratory diseases of buffaloes. Furthermore, our findings will also help the field veterinarian to treat and control the respiratory diseases of buffaloes. 


\section{REFERENCES}

1. Banerjee, G. C. 1998. A text book of Animal husbandry, 8th ed. Oxford and IBH publishing Co. Pvt. Ltd., New Delhi.

2. Bangladesh Bureau of Statistics (BBS). 2010. Agriculture: Crops, Livestock, Forestry and Fishery. Bangladesh Bureau of Statistics, Ministry of Planning, Government of the People's Republic of Bangladesh.

3. Akber, M., F. Ahmedullah, M. G. Haider and M. I. Hossain. 2007. Isolation and Identification of Bacteria from Tracheas and Lungs of Buffaloes. Bangladesh Vet J 41 (1-4): 17-22.

4. Hucker, G. J. and H. J. Conn. 1923. Methods of Gram Staining Tech. Bull. N. Y. St. Agric. Exp Sta. no.93.

5. Lillie, R. D. 1928. The Gram stain I: A quick method for staining Grampositive organisms in the tissues. Archive Pathology 5: 828 .

6. Merchant, I. A. and R. A. Packer. 1967. Veterinary Bacteriology and Virology, 7th ed. The Iowa State University Press, Ames, Iowa, USA.

7. Cowan, S. T. 1974. Cowan and Steel's Manual for the Identification of Medical Bacteria. 2nd ed. Cambridge University Press, Cambridge, UK.
8. Radostitis, O. M., D. C. Blood, and C. C. Gay. 2002. Veterinary Medicine. A text book of the diseases of cattle, sheep, pigs, goats and horses, 13th ed, Billiere Tindall, USA.

9. Acone, P., C. Guarino, and R. Izzi. 1970. An outbreak of entrotoxaemia due to Closteridium perfringens type-D in buffaloes. Italian Science of Veterinary 23: 1011-1014

10. Jubb, K.V. F., P. C. Kennedy, and N. Palmer. 1997. Veterinary Pathology, 6th ed. Williams and Wilkins, USA.

11. Shah, N. H., J. Biewenga, N. H. Shah, and F. K. Graaf. 1996. Vacuolating cytotoxic activity of Pasteurella multocida causing causing haemorrhagic septicemia in buffalo and cattle. FEMS Microbiological Letters 143: 97-101.

12. Tadayon, K., et al. 2006. The Epidemiology of Mycobacterium bovis in Buffalo in Iran. Journal of Veterinary Medicine 1: 41-42.

13. Kalema, Z. G., R. G. Bengis, A. L. Michel, and M. H. Woodford. 2005. A preliminary investigation of tuberculosis and other diseases in African buffalo (Syncerus caffer) in National Qeen Elizabeth National Park, Uganda. Onderstepoort Journal of Veterinary Research 72: 145-51. 